\title{
Benefit-cost analysis of vegetation management alternatives: An Ontario case study
}

\author{
by Krish Homagain ${ }^{1,2}$, Chander K. Shahi ${ }^{1}$, Nancy J. Luckai ${ }^{1}$, Mathew Leitch ${ }^{1}$ and F. Wayne Bell ${ }^{3}$
}

\begin{abstract}
Vegetation management practices are an integral component of forest management. In this paper, we report results of stand-level benefit-cost analyses of 12 vegetation management treatments applied at six study sites in northern Ontario. Forest Vegetation Simulator (FVS ${ }^{\text {Ontario }}$ ) was used to project gross total and merchantable volumes to 70 years of age, and BUCK-2 was used to optimize potential products. Net present value (NPV), benefit-cost ratio (BCR), and internal rate of return (IRR) were calculated using 2009 constant dollars and variable real discount rates. Aerial herbicide treatments produced the highest NPV, BCR, and IRR. Internal rates of return of $4.32 \%, 2.90 \%, 2.82 \%$ and $2.50 \%$ for aerial herbicide, manual brush cutting, ground-applied herbicide, and brush cutting plus herbicide treatments, respectively, indicated that all of the vegetation management alternatives evaluated are economically viable.
\end{abstract}

Key words: aerial herbicides, brush saw, forest economics, Forest Vegetation Simulator (FVS ${ }^{\text {Ontario}}$ ), ground herbicides, internal rate of return, net present value

\section{RÉSUMÉ}

Les pratiques de contrôle de la végétation font partie intégrante de l'aménagement forestier. Dans cet article, nous reportons des résultats obtenus par des analyses de coût-bénéfice effectuées au niveau du peuplement pour 12 traitements de contrôle de la végétation appliqués sur six sites détudes du nord de l'Ontario. Le Forest Vegetation Simulator (FVSOntario) a été utilisé pour projeter le volume total et le volume marchand à lâge de 70 ans et le BUCK-2 a été utilisé pour optimiser les produits potentiellement obtenus. La valeur actuelle nette (VAN), le ratio coût-bénéfice (RCB) et le taux de rentabilité interne (TRI) ont été calculés en dollars constants de 2009 et selon des taux variables de profitabilité réelle. Lépandage aérien de phytocide a généré les VAN, RCB et TRI les plus importants. Les taux de rentabilité interne de $4,32 \%, 2,90 \%, 2,82 \%$ et de $2,50 \%$ respectivement pour lépandage aérien, le débroussaillage manuel, lapplication terrestre de phytocide et le débroussaillage manuel suivi de traitements de phytocide, ont démontré que toutes les alternatives de contrôle de la végétation évaluées sont économiquement viables.

Mots clés : épandage aérien de phytocide, débroussailleuse, économie forestière, Forest Vegetation Simulator (FVSOntario), épandage terrestre de phytocide, taux de rentabilité interne, valeur actuelle nette

\section{Introduction}

Ontario's forest sector is a key component of the province's economy (OMNDMF 2010). Most of Ontario's productive forest is in the conifer-dominated boreal region where optimization of growth rates of spruce (Picea) and pine (Pinus) species is a key forest management objective, but these species are often out-competed by hardwoods such as poplar (Populus spp.) (Hearnden et al. 1992). Maintaining overall forest composition is a legal requirement under Ontario's Crown Forest Sustainability Act, which states that "large, healthy, diverse and productive Crown forests and their associated ecological processes and biological diversity should be conserved" (Statutes of Ontario 1995). As a result, forest vegetation management practices are an integral component of forest management.

Forest vegetation management practices help to ensure initial plantation ${ }^{4}$ survival, accelerate growth of targeted

\footnotetext{
${ }^{4}$ Plantation is a forest crop established artificially, either by sowing or by planting (NRCan 1995)
}

species, and achieve high yields in terms of per unit gross total volume production (Wagner et al. 2006). Forest vegetation management practices include several alternatives (Wiensczyk et al. 2011, this issue) and results from experimental studies on growth rates and volume production are highly variable among these alternative treatments (Comeau et al. 1999; Simard et al. 2001; Heineman et al. 2005; Bell et al. 2011a, this issue). The costs associated with the various treatments also vary greatly (Bell et al. 1997, Dampier et al. 2006).

In a system where both yields and costs vary, an economic analysis of the efficiency of a silvicultural intervention can only be evaluated based on long-term stand-level growth response data and cost information (McKenney et al. 1997). In a review of the Canadian forest vegetation management research and practice, Thompson and Pitt (2003) report 1256 scientific publications directly related to forest vegetation management as of 2002, but only 18 (1.4\%) of those include components of economic analysis of forest vegetation management treatments, and even fewer are focused on the economics associated with releasing boreal conifers. Therefore,

\footnotetext{
${ }^{1}$ Faculty of Natural Resources Management, Lakehead University, 955 Oliver Rd., Thunder Bay, Ontario P7B 5E1.

${ }^{2}$ Corresponding author. E-mail: khomagai@lakeheadu.ca

${ }^{3}$ Ontario Forest Research Institute, Ontario Ministry of Natural Resources, 1235 Queen Street East, Sault Ste. Marie, Ontario P6A 2 E5.
} 
there is a need for stand-level benefit-cost analyses (BCA) that will help decision-makers choose the best alternatives for forest vegetation management. BCA is a method of appraising and evaluating an investment decision that includes identification, valuation, and comparison of all costs and benefits during the life of a project (Campbell and Brown 2003). BCA provides the most comprehensive framework for evaluating any economic investment, as it estimates values associated with inputs and outputs for each activity (Nautiyal et al. 2001). Net present value (NPV), benefit-cost ratio (BCR) and internal rate of return (IRR) are the most commonly used measures for conducting benefit-cost analysis. NPV expresses the difference between the discounted present value of future benefits and the discounted present value of future costs, whereas BCR is the ratio of discounted present value of benefits to the discounted present value of costs. A positive NPV or a BCR greater than one indicates that the activity being evaluated is economically beneficial. We used both NPV and BCR because for investment decisions related to forestry activities, NPV gives the best comparison when silviculture budgets are not limited and BCR gives the best comparison when silviculture budgets are limited (Willcocks et al. 1997). However, both NPV and BCR depend on the discount rate used for the analysis. Therefore, the benefit-cost analysis is supplemented by finding the IRR, which is the discount rate when NPV is zero. An IRR greater than the existing market interest rates in general indicates a relatively profitable investment (Campbell and Brown 2003). Such analyses provide a management tool to evaluate and compare amongst different release treatments, thereby building a competitive, knowledge-based forest industry that is sustainable under increasing global competition.

In this paper, which is one of a series of papers related to forest vegetation management published in the March/April 2011 issue of The Forestry Chronicle (see Bell et al. 2011b, this issue), we report the results of stand-level BCA of vegetation management treatments applied at six sites in northern
Ontario. The specific objectives of the study were to: (i) calculate costs associated with each vegetation management treatment over almost two decades, (ii) estimate projected yield and value of fibre (timber, pulpwood, and hog fuel) production using a simulation and an optimization model, and (iii) conduct BCA to compare the economic viability of the vegetation management treatments.

\section{Methods}

The simulations and benefit-cost analyses presented in this paper are based on data from six Vegetation Management Alternative Program (VMAP) studies. In brief, yields were projected beyond the data to age 70 years using Forest Vegetation Simulator (FVS ${ }^{\text {Ontario}}$ ) (ESSA 2008). BUCK-2 optimization software (Zakrzewski et al. 2010) was used to determine what forest products could be produced at 70 years following treatments. Future benefits were calculated using current Thunder Bay market prices for pulpwood and hog fuel $^{1}$, and lumber prices from Random Length price statistics for 2009 (Random Lengths 2009). A range of real discount rates $(2 \%$ to $10 \%)$ was used to calculate net present value and benefit-cost ratio for each vegetation management treatment. In addition, the internal rate of return for each treatment was estimated to compare changes in NPV over different discount rates. Details of each stage of analysis are provided below following descriptions of the studies from which the data were obtained (for additional details about study sites, see Bell et al. 2011a).

\section{Study areas and vegetation management treatments}

Data collected over 10 to 16 years from six research studies in northern Ontario were used for the analysis (Table 1). All sites were clearcut harvested, mechanically site prepared

${ }^{1}$ Hog fuel consists of mix of wood residues, shavings and off-cuts that can be recovered during saw-log and pulp-log conversion.

Table 1. Vegetation management alternative program study areas, treatments, and experimental designs from which data were obtained for the benefit-cost analysis (adapted from Bell et al. 2011a)

\begin{tabular}{|c|c|c|c|c|c|c|}
\hline Study site & Location & Year planted & Crop species & Year released & Release treatments ${ }^{\mathrm{a}}$ & Exp. design (Exp. units) \\
\hline Bending Lake & $\begin{array}{l}48^{\circ} 57^{\prime} \mathrm{N} \\
92^{\circ} 02^{\prime} \mathrm{W}\end{array}$ & 1988 & jack pine & $1992-93$ & ASg, BS, CON, CRg & RCBD: 4 Blocks (16) \\
\hline Espanola & $\begin{array}{l}46^{\circ} 48^{\prime} \mathrm{N} \\
82^{\circ} 11^{\prime} \mathrm{W}\end{array}$ & $\begin{array}{l}\text { Block 1: } 1989 \\
\text { Others: } 1991\end{array}$ & jack pine & 1993 & $\begin{array}{c}\text { ASg, BBt, BS, CON, } \\
\text { CRg, MBg, }\end{array}$ & RCBD: 3 Blocks (18) \\
\hline Fallingsnow & $\begin{array}{l}48^{\circ} 08^{\prime} \mathrm{N} \\
89^{\circ} 49^{\prime} \mathrm{W}\end{array}$ & 1987-90 & white spruce & 1993 & $\begin{array}{l}\text { ASg, ASt, BS, CON, } \\
\text { CRb, CRg, SIL }\end{array}$ & RCBD: 3 Blocks (21) \\
\hline Leether Lake & $\begin{array}{l}50^{\circ} 36^{\prime} \mathrm{N} \\
91^{\circ} 45^{\prime} \mathrm{W}\end{array}$ & 1988 & $\begin{array}{l}\text { jack pine, } \\
\text { black spruce }\end{array}$ & 1993 & ASg, BS, CON, CRg & CRD: 3 Blocks (12) \\
\hline Nipigon Corrigal & $\begin{array}{l}49^{\circ} 01^{\prime} \mathrm{N} \\
88^{\circ} 10^{\prime} \mathrm{W}\end{array}$ & 1988 & black spruce & 1990 & $\begin{array}{c}\text { BBt, BSg CON, CRg, } \\
\text { EZg, RHg }\end{array}$ & RCBD: 3 Blocks (18) \\
\hline Nipigon Hele & $\begin{array}{l}48^{\circ} 59^{\prime} \mathrm{N} \\
88^{\circ} 33^{\prime} \mathrm{W}\end{array}$ & 1987 & black spruce & 1990 & CON, CRg, RHg, SGh & RCBD: 3 Blocks (12) \\
\hline
\end{tabular}


(1986-1988), and planted (1988-1991) with bareroot or container stock of jack pine (Pinus banksiana Lamb.) (three sites), black spruce (Picea mariana [Mill.] BSP) (two sites), or white spruce (Picea glauca [Moench] Voss) (one site) at approximately $2 \times 2 \mathrm{~m}$ spacing. In all, 12 vegetation management (release) treatments ${ }^{5}$ (plus untreated control) were applied to 97 experimental units (plots) varying from 2 ha to 12 ha, using randomized complete block designs with single replications. One exception is the Leether Lake site, where treatments were completely randomized in four replications. Each site has three to four blocks and four to seven treatments, but all treatments were not applied at all sites. The level of silviculture implemented at all six sites would be classified as "basic" based on the definitions provided by Bell et al. (2008). Specific site and treatment descriptions are below.

The Bending Lake Project is located about $54 \mathrm{~km}$ north of Atikokan, Ontario (Table 1). Jack pine is the crop species at this site. The study includes four blocks and four treatments: (i) aerial spray with glyphosate (ASg) in late August 1992, (ii) brush saw (BS) between late June and early July 1993, (iii) control (CON) with no release treatment, and (iv) continuous removal with ground applications of glyphosate (CRg) in September 1993 and again in August 1994.

The Espanola Study is located approximately $90 \mathrm{~km}$ northwest of Espanola, Ontario (Table 1). Jack pine is the crop species at this site. The study includes three blocks and six treatments: (i) aerial spray with glyphosate (ASg) in August 1993, (ii) basal bark/triclopyr (BBt) in October 1993, (iii) brush saw (BS) in October 1993, (iv) control (CON) with no release treatment, (v) continuous removal with ground applications of glyphosate (CRg) in June 1995 and again in June 1996, and (vi) mist blower with glyphosate (MBg) in August 1993.

The Fallingsnow Ecosystem Project is located approximately $60 \mathrm{~km}$ southwest of Thunder Bay, Ontario (Table 1). White spruce is the main crop species at this site. The study includes three blocks and seven treatments: (i) aerial spray with glyphosate (ASg) in mid-August 1993, (2) aerial spray with triclopyr (ASt) in mid-August 1993, (iii) brush saw (BS) in mid- to late October 1993, (iv) control (CON) with no release treatment, $(\mathrm{v})$ continuous removal with brush saws (CRb) in 1994 through 1997, (vi) continuous removal with ground applications of glyphosate (CRg) in 1994 through 1997, and (vii) Silvana Selective (SIL) brush cutting between late October to early November 1993.

The Leether Lake Study is located about $56 \mathrm{~km}$ north of Sioux Lookout, Ontario (Table 1). Jack pine is the crop species at this site except in blocks treated with BS, where black spruce was planted. The study includes four treatments replicated three times: (i) aerial spray with glyphosate (ASg) in August 1993, (ii) brush saw (BS) between early to mid-June 1994, (iii) control (CON) with no release treatment, and (iv) continuous removal with ground applications of glyphosate (CRg) in 1994 through 1996.

The Nipigon Hele Study is located in Hele Township, about $19 \mathrm{~km}$ west of Nipigon, Ontario (Table 1). Black spruce is the main crop species at this site. The study includes three blocks and four treatments: (i) control (CON) with no release treatments, (ii) continuous removal with ground applications

\footnotetext{
${ }^{5}$ Vegetation management treatments are sometimes referred as "release treatments". These terms are interchangeably used throughout this paper.
}

of glyphosate (CRg) from August 1990 through 1994; (iii) reel and hose application of glyphosate (RHg) in August 1991; and (iv) spot gun application of hexazinone (SGh) in October 1990. All treatments except continuous removal were applied to a $1-\mathrm{m}$ radius around each crop tree.

The Nipigon Corrigal Study is located in Corrigal Township, about $8 \mathrm{~km}$ east of Nipigon, Ontario (Table 1). Black spruce is the main crop species at this site. The study includes three blocks and six treatments: (i) basal bark application of triclopyr (BBt) in October 1990, (ii) brush saw with glyphosate (BSg) in September 1990, (iii) control (CON) with no release treatment, (iv) continuous removal with ground applied glyphosate (CRg) in August 1990 through 1994, (v) EZ-Ject application of glyphosate (EZg) in November 1990, and (vi) reel and hose application of glyphosate ( $\mathrm{RHg}$ ) in August 1991. All treatments except continuous removal, EZJect, and basal bark were applied to a 1-m radius around each crop tree.

\section{Data collection}

Crop tree plots of approximately $1200 \mathrm{~m}^{2}(30 \mathrm{~m} \times 40 \mathrm{~m})$ were established in each treatment plot, before applying the release treatment. In each treatment plot, 20 crop trees (at approximately 10 -m spacing) were selected for periodic remeasurement. We used the $10^{\text {th }}$-year post-treatment crop tree measurement data (height, diameter at breast height $(\mathrm{DBH})$ and stocking) presented in Bell et al. (2011a) and additional $16^{\text {th }}$ year post-treatment data from the Fallingsnow Ecosystem Project collected in 2009 summer for our analyses.

\section{Simulation and optimization models}

We used Forest Vegetation Simulator, FVS Ontario _ a non-spatial, individual-tree growth model (for details, see ESSA 2008) - to project expected crop tree volumes to an arbitrary rotation age of 70 years. The model simulates changes in diameter increment of individual trees using current size (diameter and height) and calibrated values of previous growth. A sub- model accumulates periodic increments over successive time intervals (e.g., five or 10 years). For each site, a common forest region (Ontario West), site quality (Site quality II), crop species, and establishment year were used. We simulated total volume assuming equal spacing between existing trees and no additional silvicultural treatments. The existing stand condition was defined using the $10^{\text {th }}$-year posttreatment measurement data for all sites, except Fallingsnow, for which $16^{\text {th }}$-year post-treatment data were used. Total tree height, diameter at breast height, number of tree stems per hectare (SPH), and stocking information were used as inputs to the simulation model, combining the data from all blocks. We projected SPH, gross total volume (GTV), gross merchantable volume (GMV), basal area (BA), quadratic mean diameter (QMD), and top height (TH) of each crop species for each treatment combination.

BUCK-2 (Zakrzewski et al. 2010) was used to optimize the possible product mix and estimate the future value of fibre produced. Projected SPH and GTV, and mean diameter and top height were used as inputs. In this optimization tool, the desired size limits (length and minimum diameter) of roundwood timber products and rankings of log categories (sawlogs, veneer logs, and pulp wood) are user-defined. Though BUCK2 does not account for the price of the output lumber, its objective is to maximize the total monetary value of a sum of the 
user-defined timber products at the tree level, where the proxy for that value is a user-defined ranking of the product. In other words, the optimum timber product mix is such that it maximizes volume proportion of the most profitable timber product at the tree level. The constraints are user-defined timber product sizes (constants): minimum top diameters and fixed log lengths. We used $2.44 \mathrm{~m}$ (8 feet) minimum length and 30 $\mathrm{cm}$ minimum diameter for the first category of sawlog (Rank I), $2.44 \mathrm{~m}$ (8 feet) minimum length and $20 \mathrm{~cm}$ minimum diameter for the second category of sawlog (Rank II), $1.22 \mathrm{~m}$ (4 feet) minimum length and $10 \mathrm{~cm}$ minimum diameter for pulp logs (Rank III), and a kerf factor of $1.5 \mathrm{~cm}$ (assuming wastage allowance for circular saw), as constraints to optimize the proportion of wood products expected from the projected

Table 2. Treatment costs, projected gross total volume and merchantable volume of crop tree species at 70 years by study site and treatment.

\begin{tabular}{|c|c|c|c|c|c|c|c|c|}
\hline \multirow[b]{2}{*}{ Metric } & \multirow[b]{2}{*}{ Treatment $\mathrm{t}^{\mathrm{a}}$} & \multicolumn{6}{|c|}{ Study sites } & \multirow[b]{2}{*}{ Average } \\
\hline & & $\begin{array}{l}\text { Bending } \\
\text { Lake }\end{array}$ & Espanola & Fallingsnow & $\begin{array}{l}\text { Leether } \\
\text { Lake }\end{array}$ & $\begin{array}{c}\text { Nipigon } \\
\text { Hele }\end{array}$ & $\begin{array}{l}\text { Nipigon } \\
\text { Corrigal }\end{array}$ & \\
\hline \multirow{13}{*}{$\begin{array}{l}\text { Costs } \\
\left(\mathrm{CAD} \$ \mathrm{ha}^{-1}\right)^{\mathrm{b}}\end{array}$} & ASg & 202.0 & 240.0 & 190.0 & 210.0 & - & - & 210.5 \\
\hline & ASt & - & - & 268.9 & - & - & - & 268.9 \\
\hline & $\mathrm{BBt}$ & - & 535.0 & - & - & - & 455.0 & 495.0 \\
\hline & BS & 550.0 & 600.0 & 500.0 & 550.0 & - & - & 550.3 \\
\hline & $\mathrm{BSg}$ & - & - & - & - & - & 625.3 & 625.3 \\
\hline & $\mathrm{CON}$ & 0.0 & 0.0 & 0.0 & 0.0 & 0.0 & 0.0 & 0.0 \\
\hline & $\mathrm{CRb}$ & - & - & 1750.0 & - & - & - & 1750.0 \\
\hline & $\mathrm{CRg}$ & 1124.8 & 1162.8 & 2011.8 & 1132.8 & 2248.9 & 2248.9 & 1655.0 \\
\hline & $\mathrm{EZg}$ & - & - & - & - & - & 910.3 & 910.3 \\
\hline & $\mathrm{MBg}$ & - & 475.3 & - & - & - & - & 475.3 \\
\hline & $\mathrm{RHg}$ & - & - & - & - & 426.6 & 395.0 & 410.8 \\
\hline & SGh & - & - & - & - & 675.3 & - & 675.3 \\
\hline & SIL & - & - & 650.3 & - & - & - & 650.3 \\
\hline \multirow{13}{*}{$\begin{array}{l}\text { GTV } \\
\left(\mathrm{m}^{3} \mathrm{ha}^{-1}\right)^{\mathrm{c}}\end{array}$} & $\mathrm{ASg}$ & 205 & 232 & 260 & 208 & - & - & 226.3 \\
\hline & ASt & - & - & 287 & - & - & - & 287.5 \\
\hline & $\mathrm{BBt}$ & - & 165 & - & - & - & 169 & 167.0 \\
\hline & BS & 167 & 172 & 248 & 169 & - & - & 189.0 \\
\hline & $\mathrm{BSg}$ & - & - & - & - & - & 177 & 177.0 \\
\hline & $\mathrm{CON}$ & 182 & 181 & 204 & 179 & 131 & 153 & 171.6 \\
\hline & $\mathrm{CRb}$ & - & - & 299 & - & - & - & 299.0 \\
\hline & CRg & 288 & 280 & 302 & 296 & 180 & 190 & 256.1 \\
\hline & $\mathrm{EZg}$ & - & - & - & - & - & 170 & 170.3 \\
\hline & $\mathrm{MBg}$ & - & 251 & - & - & - & - & 250.7 \\
\hline & $\mathrm{RHg}$ & - & - & - & - & 196 & 186 & 191.1 \\
\hline & SGh & - & - & - & - & 169 & - & 168.7 \\
\hline & SIL & - & - & 255 & - & - & - & 255.0 \\
\hline \multirow{12}{*}{$\begin{array}{l}\text { Merchantable volume } \\
\left(\mathrm{m}^{3} \mathrm{ha}^{-1}\right)^{\mathrm{c}, \mathrm{d}}\end{array}$} & $\mathrm{ASg}$ & $173(5)$ & $186(5)$ & $208(51)$ & 185 (157) & - & - & $188(54)$ \\
\hline & $\mathrm{BBt}$ & - & $132(70)$ & - & - & - & $132(147)$ & $132(108)$ \\
\hline & BS & $159(3)$ & $138(6)$ & $199(114)$ & $142(72)$ & - & - & $159(49)$ \\
\hline & BSg & - & - & - & - & - & $138(120)$ & $138(120)$ \\
\hline & $\mathrm{CON}$ & $154(60)$ & 145 (109) & $163(172)$ & $153(252)$ & $104(60)$ & $124(100)$ & $140(126)$ \\
\hline & $\mathrm{CRb}$ & - & - & $260(9)$ & - & - & - & $260(9)$ \\
\hline & CRg & $244(2)$ & $224(2)$ & $266(1)$ & $254(73)$ & $148(2)$ & $150(16)$ & $214(16)$ \\
\hline & $\mathrm{EZg}$ & - & - & - & - & - & $138(218)$ & $138(218)$ \\
\hline & $\mathrm{MBg}$ & - & $201(11)$ & - & - & - & - & $201(11)$ \\
\hline & $\mathrm{RHg}$ & - & - & - & - & $155(23)$ & $147(53)$ & $151(38)$ \\
\hline & SGh & - & - & - & - & $133(91)$ & - & $133(91)$ \\
\hline & SIL & - & - & $204(135)$ & - & - & - & 204 (135) \\
\hline
\end{tabular}

aTreatment descriptions: ASg - aerial application of Vision (glyphosate) from a Bell 206 helicopter; ASt - aerial application of Release (triclopyr) from a Bell 206 helicopter; BBt basal Bark application of Release (triclopyr) with backpack sprayer (Thin Line); BS - motor-manual brush saw cutting at $18 \mathrm{~cm}$ above ground without herbicide; BSg - brush saw cutting with stump herbicide applicator attachment with Vision (glyphosate); CON - untreated control; CRb - continuous removal of vegetation by annual applications of brush saws; CRg - continuous removal of vegetation by annual applications of Vision (glyphosate); EZg - EZ-Ject injection of Vision (glyphosate) into competing basal stem; MBg - Backpack mist blower application of Vision (glyphosate); RHg - Reel and hose application of Vision (glyphosate); SGh - spot gun application of Velpar-L (hexazinone); SIL - mechanical brush cutting at $33 \mathrm{~cm}$ above ground with Silvana Selective/Ford Versatile tractor

${ }^{\mathrm{b}}$ Costs are based on non-crop stocking level and distance of the site from the nearest major centre and are calculated on a 500-ha plot basis.

${ }^{\mathrm{c}}$ Volumes were projected using FVS ${ }^{\text {Ontario. }}$.

${ }^{\mathrm{d}}$ Values in parentheses are the non-crop (hardwoods - mainly poplar) merchantable volumes. 
GMV produced by trees subjected to different vegetation management treatments. Only the merchantable volume of the target crop species was optimized.

\section{Benefit-cost analysis}

First, the costs (site preparation, planting, release treatment, harvesting, transportation, and overhead and administration costs) associated with each vegetation management treatment were collected. Because exact costs were not available for each site, data were collected from several sources and averaged.

nication, 2010), and Jack Fish River Forest Management Inc. Hornepayne, Ontario (Jerry Smith, personal communication, 2010). Site preparation, planting, and treatment costs were estimated on a 500-ha basis at 2009 values for each site and treatment. Treatment and site preparation costs varied with non-crop stocking, which was based on $10^{\text {th }}$-year post-treatment stocking data (Pitt and Bell 2005). Harvesting and transportation costs are estimated based on GTV and GMV for each site. A $10 \%$ overhead cost was added to offset managerial and administrative costs.

Second, the value of lumber that could be recovered from 70-year projected stem volumes for the different treatments was calculated using forest product market prices and statistics for 2009 (December average) (Random Lengths 2009). Lumber prices were calculated by averaging prices given for spruce-pine-fir, eastern green lumber for $2 \times 4$ s, precision end trimmed (PET), stud grade, \#1 and \#2, and random. Pulp wood and hog fuel values were estimated based on current Thunder Bay, Ontario mill gate prices (Buchanan Pulp Sales Office, personal communication, 2009). The treatment benefits were calculated based on 2009 average prices (CAD \$235.5 per mbf for SPF lumber, CAD \$31.34 per green ton for pulpwood, and CAD \$25.07 per green ton for hog fuel). The non-crop merchantable value was calculated based on hardwood prices, which varied from species to species (ranging from CAD $\$ 150$ to CAD $\$ 300.00$ per mbf). Lumber and other wood product prices in 2009 were low in comparison to the previous 10

Data sources included individuals (Al Stinson, OMNR, personal communication, 2010), British Columbia case studies (Boateng 1996, D’Anjou 1996, Thorpe 1996, Comeau and Harper 2009), Ontario case studies (McClain et al. 1994; Willcocks et al. 1997; Bell et al. 1997; Pitt et al. 2000; Pitt et al. 2004; Dampier et al. 2006; Dacosta et al. 2011, this issue), and a Quebec case study (Fortier and Messier 2006). Cost estimates for the aerial application of herbicides are based on data previously published from the studies of interest (Bell et al. 1997, Dampier et al. 2006) and current estimates provided by Zimmer Air Services Inc., Thunder Bay and Jack Fish River Forest Management Inc., Hornepayne, Ontario. Herbicide costs for 2009 were collected from E.I. du Pont Canada Company, Engage Agro Corp (a Monsanto Canada dealer), TrueNorth Specialty Products (a Univar company), and Dow AgroSciences Canada Inc. Brush cutting and labour cost estimates came from Haveman Brothers Forestry Services, Kakabeka Falls, Thunder Bay (Dave Haveman, personal commu- years (2000-2009). We also conducted a sensitivity analysis to see the effect of changed wood prices on NPV and BCR using 2005 average prices, which were high for most products during 2000 to 2009. Since we did not have real future market price and cost information, we discounted benefits and costs estimates to the year 2009, under the assumption that benefits and costs will follow similar trends in the future.

Third, the benefit-cost analysis was conducted using NPV and BCR, as specified in equations [1] and [2], respectively.

$$
N P V=\sum \frac{B}{(1+r)^{t}}-\sum \frac{C}{(1+r)^{t}}
$$

[2] $\quad \mathbf{B C R}=\frac{\sum \frac{\mathbf{B}}{(1+\mathbf{r})^{\mathrm{t}}}}{\sum \frac{\mathbf{C}}{(1+\mathbf{r})^{\mathrm{t}}}}$ 
(a)

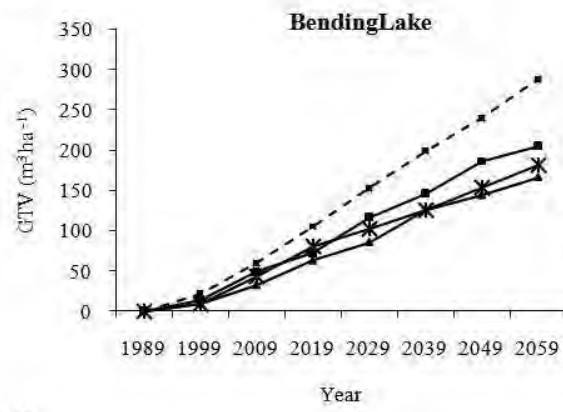

(c)

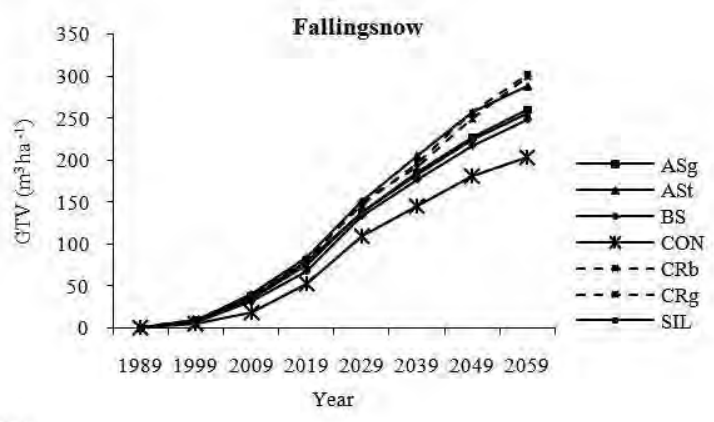

(e)

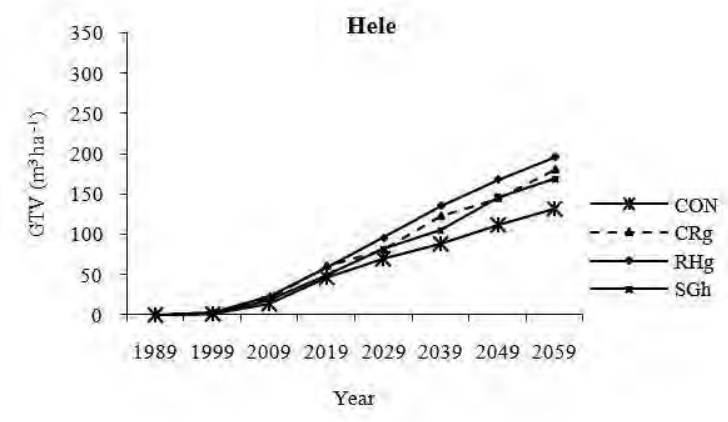

(b)

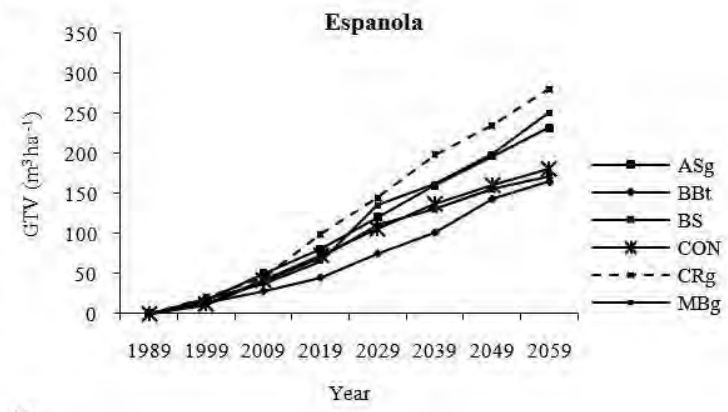

(d)

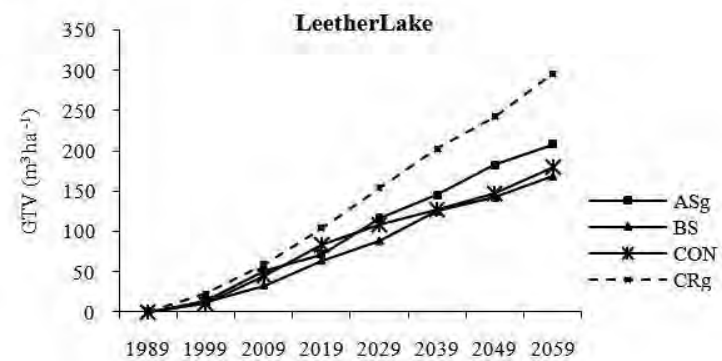

Year

(f)

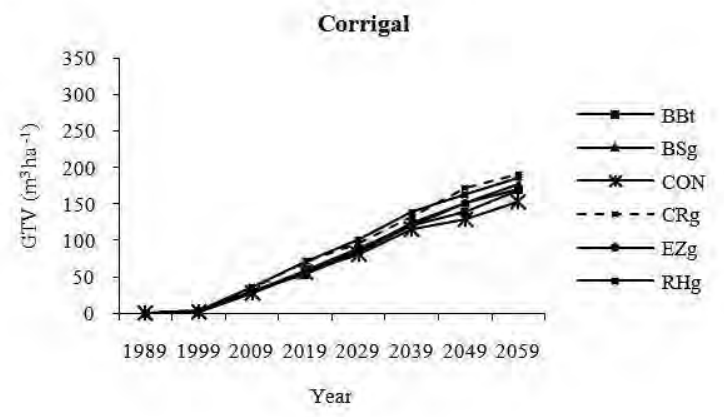

Fig. 2. Projected gross total volume (GTV; $\mathrm{m}^{3} \mathrm{ha}^{-1}$ ) of crop trees from various vegetation management studies. Volumes were projected using FVS Ontario. ASg - aerial spray with glyphosate, ASt - aerial spray with triclopyr, BBt - basal bark application of triclopyr, BS brush saw, BSg - brush saw cutting with glyphosate, CON - control, CRb - continuous removal by brush saws, CRg - continuous removal by glyphosate, EZg - EZ-Ject injection of glyphosate, $\mathrm{MBg}$ - mist blower application of glyphosate; RHg - reel and hose application of glyphosate, SGh - spot gun with hexazinone, SIL - mechanical cutting with Silvana Selective/Ford Versatile tractor. Treatment details are summarized in Table 1.

where B and C are benefits and costs, respectively, associated with each vegetation management treatment over time $t$, and $\mathrm{r}$ is the discount rate.

Both NPV and BCR depend on the discount rate used for analysis. For private land forestry situations, the discount rate corresponds to the opportunity cost of capital (Johansson and Löfgren 1985). Several different discount rates, ranging from $0 \%$ to $20 \%$, are commonly used to evaluate private forestry investments (Manley 2010) but historical social discount rates range from 3\% to 5\% (Heaps and Pratt 1989). Given current market competitive interest rates offered by commercial banks, we used a real discount rate ranging from $2 \%$ to $10 \%$ to assess the sensitivity of NPV and BCR. We also computed the internal rate of return (IRR), which is the discount rate when NPV equals zero and provides a measure of the profitability of an investment excluding environmental factors (Campbell and Brown 2003) for each treatment. 
(a)

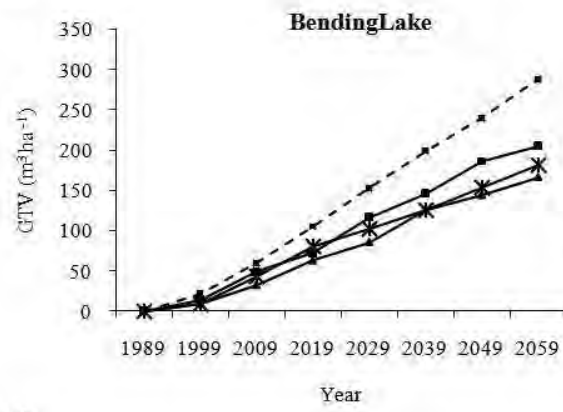

(c)

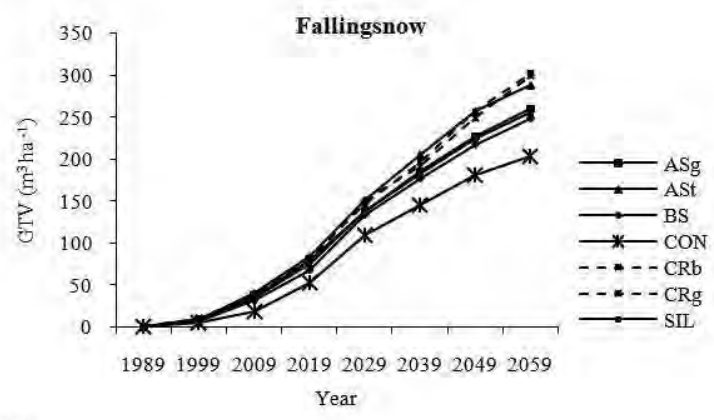

(e)

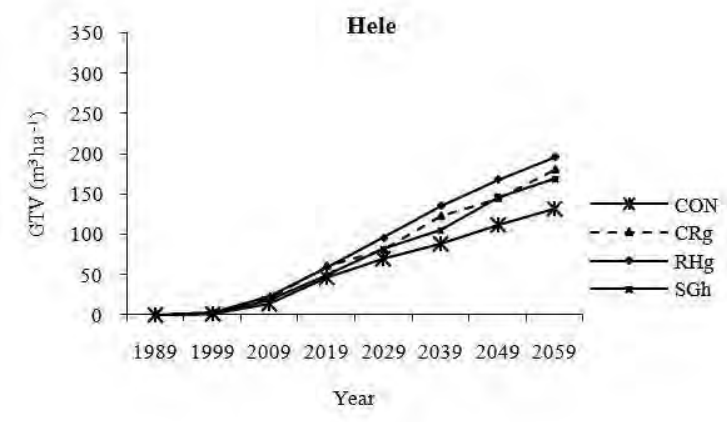

(b)

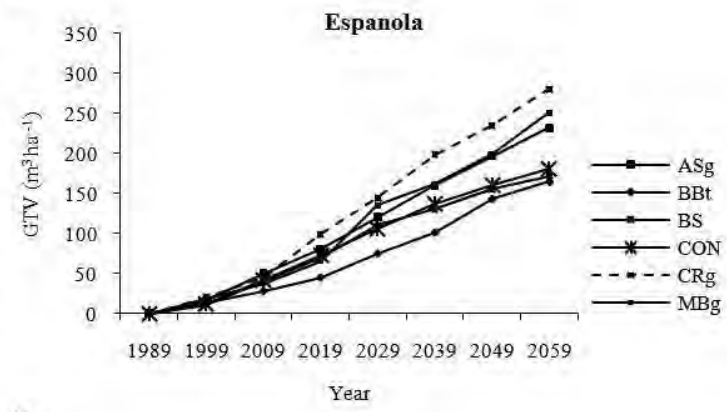

(d)

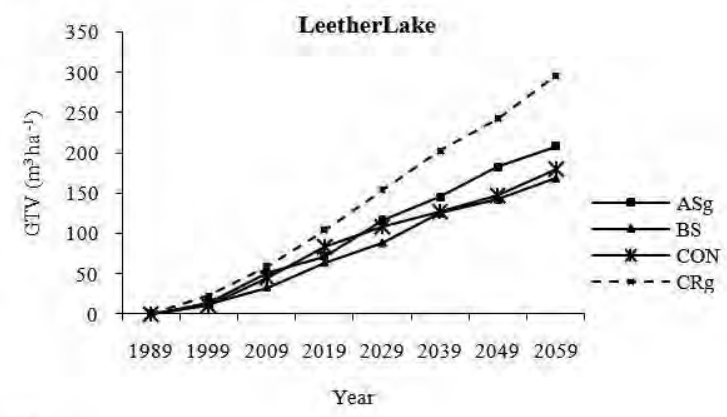

(f)

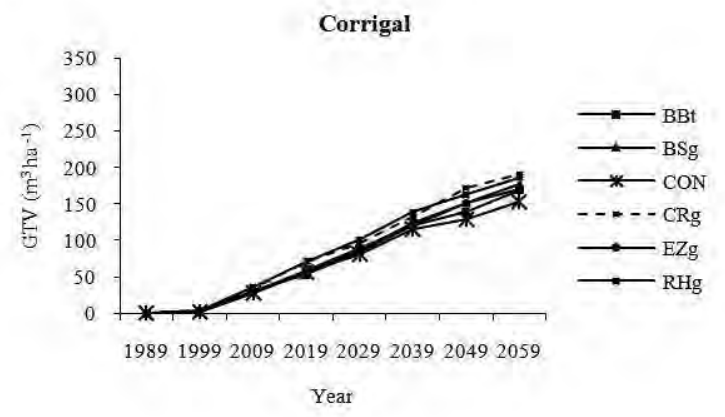

Fig. 3. Projected gross merchantable volume (GMV; $m^{3} h^{-1}$ ) of crop trees from various vegetation management studies. Volumes were projected using FVS Ontario. ASg - aerial spray with glyphosate, ASt - aerial spray with triclopyr, BBt - basal bark application of triclopyr, BS - brush saw, BSg - brush saw cutting with glyphosate, CON - control, CRb - continuous removal by brush saws, CRg - continuous removal by glyphosate, EZg - EZ-Ject injection of glyphosate, $\mathrm{MBg}$ - mist blower application of glyphosate; RHg - reel and hose application of glyphosate, SGh - spot gun with hexazinone, SIL - mechanical cutting with Silvana Selective/Ford Versatile tractor. Treatment details are summarized in Table 1.

\section{Results}

The results of benefit-cost analyses are presented by site and treatment. Since not all treatments were replicated at all sites, we calculated the averages of benefits and costs from each treatment-site combination. Further we grouped the results in four treatment groups: aerially applied herbicide (ASg, $\mathrm{ASt}$ ), ground-applied herbicide (BBt, EZg, $\mathrm{MBg}, \mathrm{RHg}$ and SGh), cutting (BS and SIL), and cutting plus herbicide (BSg). Continuous removal treatments $(\mathrm{CRg}$ and $\mathrm{CRb})$ were not considered in the NPV and BCR calculations because costs associated with these treatments are very high and these treatments are neither recommended nor used in practice.

\section{Treatment costs}

Costs associated with each treatment at each site are presented in Table 2. On average, ASg had the lowest per-unit cost (CAD\$210.50 per ha) followed by ASt (CAD\$268.90 per ha). Costs of continuous removal treatments are always 


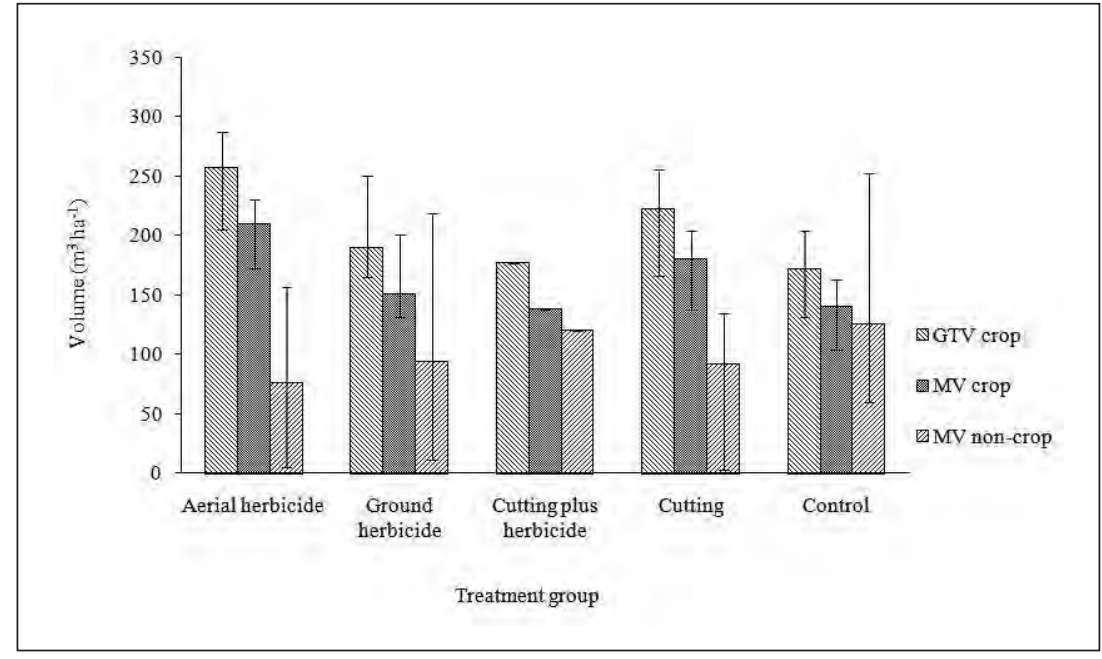

Fig. 4. Projected average gross total (GTV) and merchantable volume (MV) ( $\mathrm{m}^{3} \mathrm{ha}^{-1}$ ) of woody vegetation at 70 years (2059) following vegetation management treatments by treatment group. Volumes were projected using FVS ${ }^{\text {Ontario. }}$. Aerial herbicide includes $\mathrm{ASg}$ and ASt; ground herbicide includes BBt, EZg, MBg, RHg, SGh; cutting plus herbicide includes BSg; and cutting includes BS and SIL treatments. Treatment details are presented in Table 1. Bars show the minimum and maximum ranges in respective treatment groups. Non-crop merchantable volumes were obtained from Bell et al. (2011a, this issue).

higher as the treatments are repeated for three to five years; for example, $\mathrm{CRb}$, which was repeated four times after the initial treatment, had the highest cost (CAD $\$ 1750.00$ per ha). A comparison among the four treatment groups revealed that aerial herbicide treatment was more cost-effective than the ground herbicide application, cutting, and cutting plus herbicide alternatives (Fig. 1a). Average total cost including site preparation, planting, treatment, harvesting, transportation, and overhead ranged from CAD $\$ 5870.40$ per ha (control) to CAD $\$ 6663.30$ per ha (cutting) (Fig. 1b). Interestingly, vegetation management treatment costs accounted for only $8 \%$ of the total costs of producing fibre (Fig. 1c).

\section{Total and merchantable volume}

Projected GTV and GMV of crop species at 70 years for each site and treatment are presented in Table 2. Fig. 2 and Fig. 3 show the overall trends in GTV and GMV, respectively. Compared to other treatments, continuous removal and aerial herbicide treatments produced higher average GTV per ha followed by mechanical cutting alternatives. Average GTV within treatment groups ranged from $172 \mathrm{~m}^{3} \mathrm{ha}^{-1}$ for the control to $257 \mathrm{~m}^{3} \mathrm{ha}^{-1}$ for aerial herbicide treatments. All treatment groups exhibited a considerable gain (from 3\% in cutting plus herbicide to $49.7 \%$ in aerial herbicide) in average GTV at age 70 compared to the controls.

A similar trend was observed for average GMV gain in treated relative to control plots. However, herbicide plus cutting (BSg) produced about $2 \%$ less GMV than that of the controls averaged across all sites. This treatment (BSg) produced about $8 \%$ more merchantable volume than the control of its site (Table 2). Non-crop merchantable volumes were always higher in control plots followed by cutting and herbicide groups (Fig. 4).

\section{Value of fibre production}

The estimated values of fibre produced by crop and non-crop species at 70 years following treatments are presented in Table 3 . The expected value at crop rotation includes both crop and non-crop merchantable volumes and values associated with potential products as optimized by BUCK-2. The aerial herbicide treatment group had the highest average value (CAD\$25 492 per ha) compared to the controls (CAD\$17 745 per ha). However, all treatments did not produce higher values than the controls at all sites. For example, BS at Leether Lake and RHg at Nipigon Corrigal produced $19 \%$ and $10 \%$ less value per hectare, respectively, than the control group. A comparison of the average value of fibre produced at different sites indicated that, on average, fibre value was higher for Fallingsnow than for the other study sites.

\section{Net present value and benefit-cost ratio}

Net present values and benefit-cost ratios for different vegetation management treatment groups computed at different discount rates with sensitivity analysis of "high" and "low" lumber prices are presented in Fig. 5 and Fig. 6. In general, the aerial herbicide group had the highest NPV and BCR for all discount rates followed by cutting and other herbicide groups. As expected, NPV was always higher for all species combined than for crop species alone (Table 4). However, at lower discount rates crop species produced higher BCR than that for all species combined. At a $2 \%$ discount rate, aerial herbicide applications produced more than double (for crop species) and more than triple (for all crop and non-crop species) the NPV than other treatment groups. The NPV for trees in the aerial herbicide treatment group was positive up to a $4 \%$ discount rate whereas trees in the other treatment groups had negative NPV for discount rates from $3 \%$ and above. At the highest discount rate (10\%), all NPV values were negative; the aerial herbicide group had the highest NPV followed by cutting and ground herbicides. However, at the lowest discount rate $(2 \%)$ ground herbicides had higher NPV than the cutting treatment.

\section{Internal rates of return}

The IRR for each treatment group for crop and all (crop and non-crop) species is presented in Table 4. Fig. 7a (crop species) and Fig. 7b (crop and non-crop species combined) illustrate the NPV at different discount rates. The aerial herbicide treatment group produced the highest IRR $(4.32 \%$ for crop species and $4.49 \%$ for all species), whereas treatments that involved cutting plus herbicides had the lowest IRR (2.50\%) for crop species, and cutting alone had the lowest IRR (3.02\%) for all woody species combined. 
Table 3. Crop and non-crop merchantable volumes, product proportions, and value of fibre production at age 70 following vegetation management treatments

\begin{tabular}{|c|c|c|c|c|c|c|c|c|}
\hline \multirow[b]{2}{*}{$\begin{array}{l}\text { Study site - } \\
\text { crop species }\end{array}$} & \multirow[b]{2}{*}{ Treatment } & \multicolumn{4}{|c|}{ Crop } & \multirow[b]{2}{*}{$\begin{array}{l}\text { Non-crop }^{\mathrm{a}} \\
\text { merchantable } \\
\text { volume } \\
\left(\mathrm{m}^{3} \mathrm{ha}^{-1}\right)\end{array}$} & \multirow[b]{2}{*}{$\begin{array}{l}\text { Value of fibre } \\
\text { production } \\
\text { e in } 2059 \\
\text { (CAD\$ per ha) } \\
\text { at } 2009 \text { price }\end{array}$} & \multirow[b]{2}{*}{$\begin{array}{c}\text { Difference } \\
\text { from } \\
\text { CON (\%) }\end{array}$} \\
\hline & & $\begin{array}{c}\text { Merchantable } \\
\text { volume } \\
\left(\mathrm{m}^{3} \mathbf{h a}^{-1}\right)\end{array}$ & $\begin{array}{c}\text { Lumber } \\
\text { (mbf per ha) }\end{array}$ & $\begin{array}{c}\text { Pulp } \\
\text { volume } \\
\text { (metric } \\
\text { ton per ha) }\end{array}$ & $\begin{array}{l}\text { Hog fuel } \\
\text { volume } \\
\text { (metric } \\
\text { ton per ha) }\end{array}$ & & & \\
\hline \multirow{4}{*}{$\begin{array}{l}\text { Bending Lake - } \\
\text { jack pine }\end{array}$} & $\mathrm{ASg}$ & 173 & 61 & 20 & 3.6 & 4.5 & 18373.71 & 5 \\
\hline & $\mathrm{BS}$ & 159 & 59 & 25 & 1.6 & 3.1 & 18127.03 & 4 \\
\hline & $\mathrm{CON}$ & 154 & 53 & 20 & 4.2 & 60.2 & 17418.91 & 0 \\
\hline & $\mathrm{CRg}$ & 244 & 89 & 23 & 4.1 & 1.9 & 21972.07 & 21 \\
\hline \multirow{6}{*}{$\begin{array}{l}\text { Espanola - } \\
\text { jack pine }\end{array}$} & $\mathrm{ASg}$ & 186 & 65 & 22 & 4.4 & 5.0 & 20445.92 & 3 \\
\hline & $\mathrm{BBt}$ & 132 & 45 & 19 & 1.8 & 69.7 & 20172.27 & 2 \\
\hline & BS & 138 & 46 & 20 & 3.7 & 6.2 & 20061.30 & 2 \\
\hline & $\mathrm{CON}$ & 145 & 48 & 23 & 2.9 & 109.3 & 19730.54 & 0 \\
\hline & $\mathrm{CRg}$ & 224 & 80 & 25 & 3.6 & 1.8 & 19843.23 & 1 \\
\hline & $\mathrm{MBg}$ & 201 & 69 & 26 & 4.4 & 10.8 & 20954.81 & 6 \\
\hline \multirow{7}{*}{$\begin{array}{l}\text { Fallingsnow - } \\
\text { white spruce }\end{array}$} & $\mathrm{ASg}$ & 208 & 74 & 25 & 2.9 & 51.2 & 25176.53 & 27 \\
\hline & $\mathrm{ASt}$ & 230 & 84 & 25 & 1.6 & 96.7 & 28209.35 & 34 \\
\hline & BS & 199 & 60 & 43 & 4.0 & 113.6 & 22839.00 & 19 \\
\hline & $\mathrm{CON}$ & 163 & 53 & 29 & 2.7 & 172.0 & 18486.76 & 0 \\
\hline & $\mathrm{CRb}$ & 260 & 92 & 33 & 3.6 & 9.0 & 23519.30 & 21 \\
\hline & $\mathrm{CRg}$ & 266 & 94 & 32 & 3.9 & 1.0 & 24351.49 & 24 \\
\hline & SIL & 204 & 74 & 22 & 3.0 & 134.8 & 25392.05 & 27 \\
\hline \multirow{4}{*}{$\begin{array}{l}\text { Leether Lake - } \\
\text { jack pine and } \\
\text { black spruce }\end{array}$} & $\mathrm{ASg}$ & 185 & 65 & 24 & 2.3 & 156.5 & 27102.68 & 24 \\
\hline & $\mathrm{BS}$ & 142 & 49 & 19 & 3.1 & 71.6 & 17182.74 & -19 \\
\hline & $\mathrm{CON}$ & 153 & 51 & 22 & 4.2 & 252.1 & 20491.29 & 0 \\
\hline & CRg & 254 & 89 & 32 & 4.1 & 72.7 & 27201.24 & 25 \\
\hline \multirow{4}{*}{$\begin{array}{l}\text { Nipigon Hele - } \\
\text { black spruce }\end{array}$} & $\mathrm{CON}$ & 104 & 35 & 14 & 3.5 & 60.1 & 12973.71 & 0 \\
\hline & $\mathrm{CRg}$ & 148 & 51 & 18 & 3.9 & 1.9 & 12878.50 & -1 \\
\hline & $\mathrm{RHg}$ & 155 & 52 & 22 & 3.3 & 23.3 & 14773.93 & 12 \\
\hline & SGh & 133 & 44 & 20 & 3.4 & 91.1 & 17545.13 & 26 \\
\hline \multirow{6}{*}{$\begin{array}{l}\text { Nipigon Corrigal - } \\
\text { black spruce }\end{array}$} & $\mathrm{BBt}$ & 132 & 44 & 18 & 5.5 & 146.8 & 21327.17 & 19 \\
\hline & $\mathrm{BSg}$ & 138 & 46 & 23 & 0.3 & 119.5 & 20046.93 & 13 \\
\hline & $\mathrm{CON}$ & 124 & 41 & 19 & 3.5 & 99.6 & 17370.92 & 0 \\
\hline & $\mathrm{CRg}$ & 150 & 49 & 18 & 5.3 & 16.2 & 17012.61 & -2 \\
\hline & $\mathrm{EZg}$ & 138 & 49 & 17 & 1.2 & 218.3 & 27401.07 & 37 \\
\hline & $\mathrm{RHg}$ & 147 & 48 & 23 & 5.0 & 52.7 & 15767.31 & -10 \\
\hline
\end{tabular}

${ }^{a}$ Non-crop volume was obtained from Bell et al. (2011a, this issue) and includes commercial softwoods and hardwoods including poplar. Crop volumes were projected using FVSOntario. Treatment descriptions are provided in Table 1. Proportions of lumber, pulp, and hog-fuel volumes for crop trees were optimized using BUCK-2 (Zakrzewski et al. 2010).

\section{Discussion}

The study results indicate that the aerial herbicide treatment group provided the most cost-effective treatments, resulted in the highest GTV and GMV, highest average value of fibre produced, and highest NPV, BCR, and IRR when compared to ground herbicide application, cutting, and cutting plus herbicide treatments. Although herbicides are cost-effective, their use in forest management continues to be contentious affecting operations in the forestry sector (Wyatt et al. 2011, this issue). At the same time, the need for forest vegetation management to favour certain species and increase the productivity of Crown forests is also recognized (see Wiensczyk et al. 2011).
Silvicultural ground rules (SGRs) and regeneration standards are used throughout Canada as tools to assess the sustainability of forest management and to help determine if desired objectives are being met (Armson 2005, Buda and White 2007). Vegetation management treatments are included in SGRs to ensure conifers are sufficiently released from competitive vegetation to ensure that regeneration standards are met. Currently, herbicide and cutting with brush saws are commonly applied in Canadian forests; however, evidence suggests that herbicides are the more effective treatment. A survey of plantations not treated with herbicides, conducted by the Nova Scotia Department of Natural 


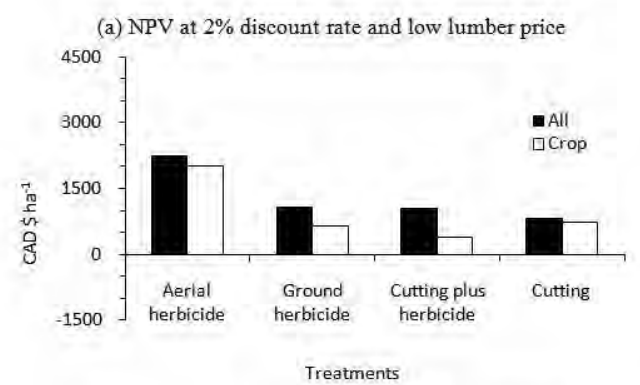

(b) NPV at $4 \%$ discount rate and low lumber price

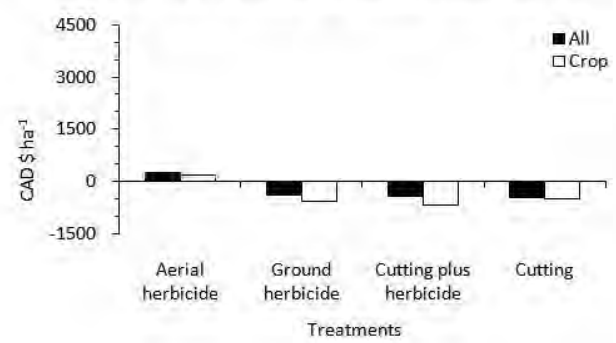

(c) NPV at $6 \%$ discount rate and low lumber price

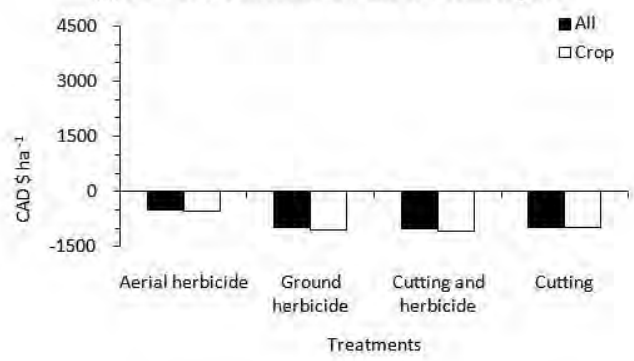

(d) NPV at $10 \%$ discount rate and low lumber price

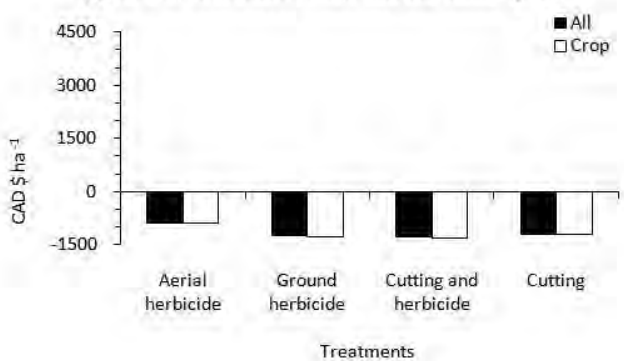

(e) $\mathrm{BCR}$ at $2 \%$ discount rate and low lumber price

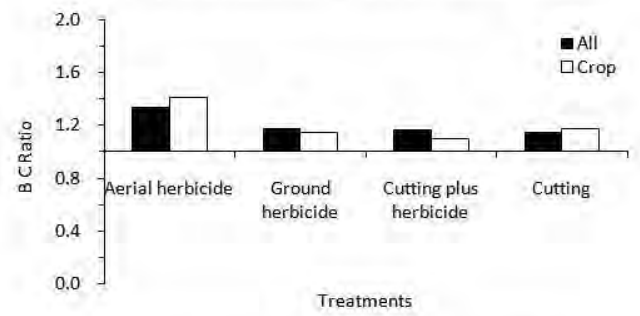

(f) $\mathrm{BCR}$ at $4 \%$ discount rate and low lumber price

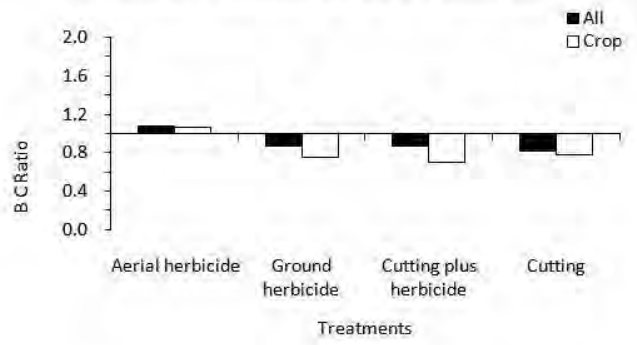

(g) BCR at $6 \%$ discount rate and low lumber price

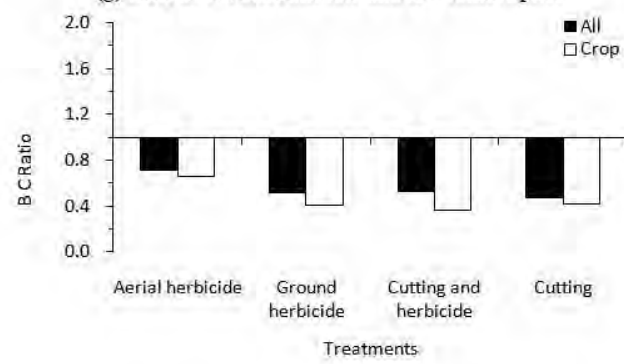

(h) BCR at $10 \%$ discount rate and low lumber price

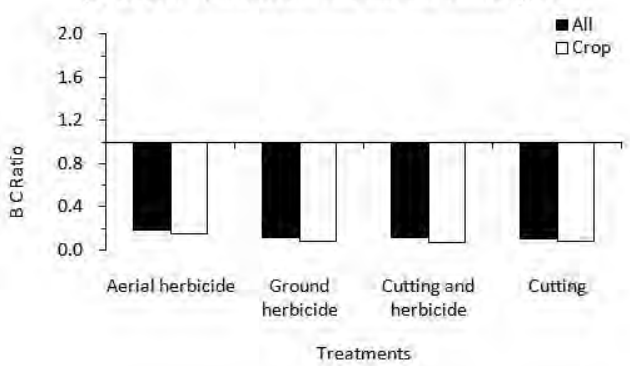

Fig. 5. Net present values (NPV; a-d) and benefit-cost ratios (BCR; e-h) at different discount rates and low lumber prices for alternative vegetation management treatments. Aerial herbicide includes $\mathrm{ASg}$ and $\mathrm{ASt}$; ground herbicide includes $\mathrm{BBt}, \mathrm{EZg}, \mathrm{MBg}, \mathrm{RHg}, \mathrm{SGh}$; cutting plus herbicide includes BSg; cutting includes BS and SIL treatments. Treatment details are presented in Table 1.

Resources, indicated that only $2.7 \%$ of surveyed areas met provincial plantation success criteria (Nicholson 2007). Therefore, herbicide-free forest vegetation management strategies, which have been implementing in Quebec since 2001 when the province banned the use of forest herbicides in commercial forestry, pose major challenges to intensive silviculture, especially where high volumes of lumber and fibre are expected. To deal with these challenges, in Quebec, four alternative strategies are being implemented. These are: preventive silviculture and natural regeneration, mechanical site preparation, early planting of size-adapted stock, and use of mechanical release where and when needed (Thiffault and Roy 2010).

The common alternative to herbicides is cutting either by motor-manual or mechanical means (Wiensczyk et al. 2011). We found that applying a cutting treatment once, although 
(a) NPV at $2 \%$ discount rate and higher lumber prices

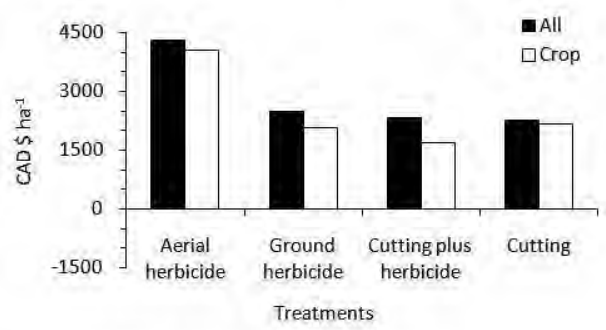

(b) NPV at 4\% discount rate and higher lumber prices

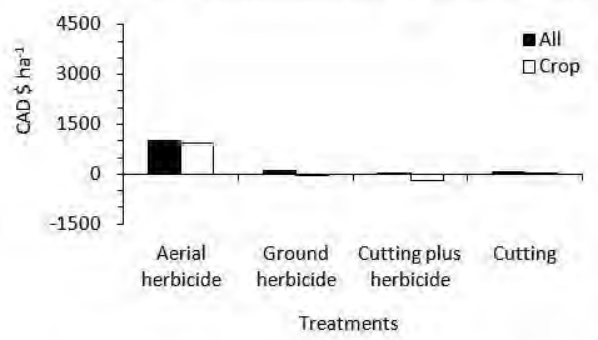

(c) NPV at $6 \%$ discount rate and higher lumber prices

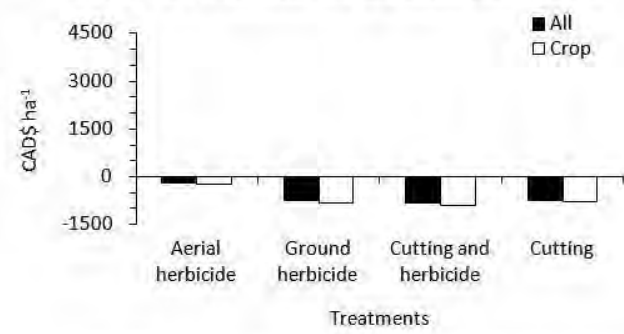

(d) NPV at 10\% discount rate and higher lumber prices

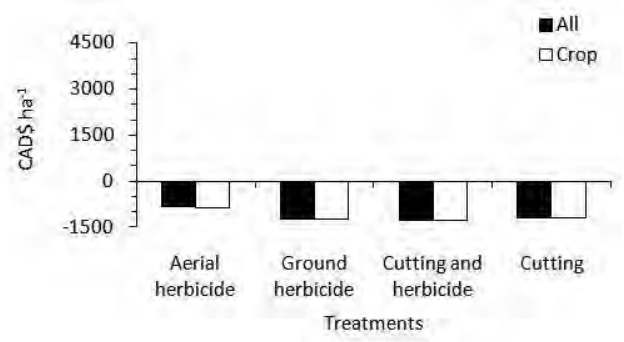

(e) BCR at $2 \%$ discount rate and higher lumber prices

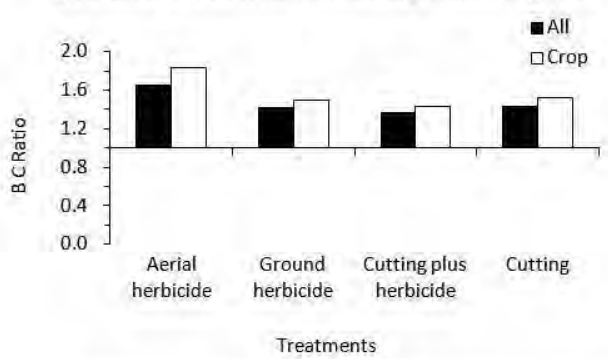

(f) BCR at $4 \%$ discount rate and higher lumber prices

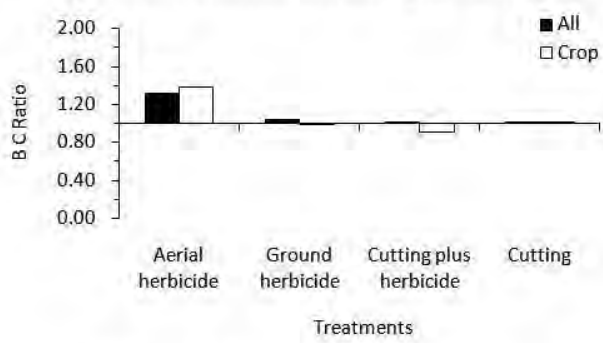

(g) $\mathrm{BCR}$ at $6 \%$ discount rate and higher lumber prices

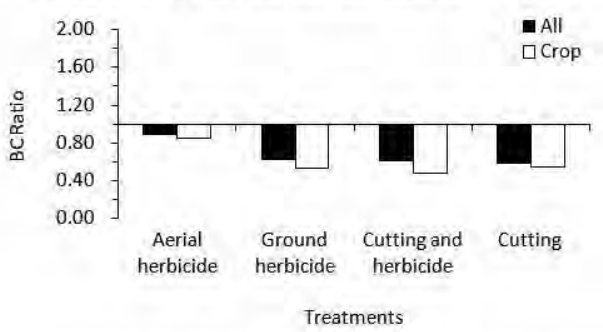

(h) BCR at $10 \%$ discount rate and higher lumber prices

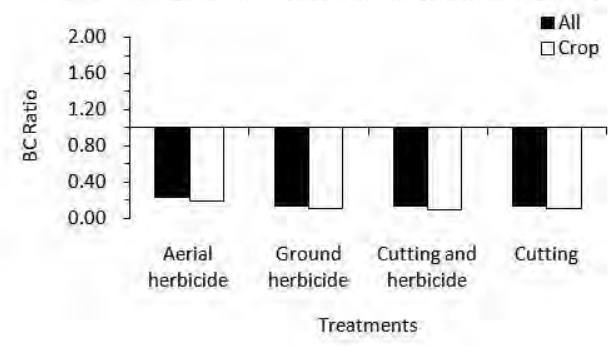

Fig. 6. Net present values (NPV; a-d) and benefit-cost ratios (BCR; e-h) at different discount rates and high lumber prices for alternative vegetation management treatments. Aerial herbicide includes ASg and ASt; ground herbicide includes BBt, EZg, MBg, RHg, SGh; cutting plus herbicide includes BSg; cutting includes BS and SIL treatments. Treatment details are presented in Table 1.

not as profitable as aerial application of herbicides, is economically viable. However, in some scenarios a single cutting operation may not be sufficient to suppress the competition (MacDonald and Fiddler 1993, Heineman et al. 2005) and repeated cutting operations are not cost-effective (Comeau and Harper 2009). Although job creation was a major goal of implementing these labour-intensive methods on a large scale, companies now frequently report a shortage of available (willing) workers to carry out mechanical release treatments (Thiffault and Roy 2010; Wyatt et al. 2011). Risks of gasoline and oil spillage, and inhalation of exhaust emissions from brush saws pose potential environmental and health risks (Dubeau et al. 2003). Additionally, mechanical cutting can damage up to $7 \%$ of planted seedlings (K. Ride, OMNR, unpublished data). Swift and Bell (2011, this issue) discuss additional environmental consequences of using these and other forest vegetation management alternatives.

Costs for cutting treatments are highly dependent on the average stocking of competing vegetation during the treatment. The treatment costs also depend on the terrain, 
Table 4. Net present value (NPV; CAD\$ per ha), benefit-cost ratio (BCR), and internal rate of return (IRR; \%) compared with average projected revenue at age 70 for vegetation management alternatives by treatment groups

\begin{tabular}{|c|c|c|c|c|c|c|c|}
\hline \multirow[b]{2}{*}{ Treatment groups } & \multicolumn{3}{|c|}{ Crop species } & \multicolumn{3}{|c|}{ All species } & \multirow{2}{*}{$\begin{array}{l}\text { Average revenue from } \\
\text { all species at age } 70 \\
\left(\mathrm{CAD} \$ \mathrm{ha}^{-1}\right) \text { in } 2009 \text { prices }\end{array}$} \\
\hline & $\mathrm{NPV}^{\mathbf{a}}$ & $\mathrm{BCR}^{\mathrm{a}}$ & IRR\% & $\mathrm{NPV}^{\mathbf{a}}$ & $\mathbf{B C R}^{\mathrm{a}}$ & IRR\% & \\
\hline Aerial herbicide & 2249 & 1.33 & 4.32 & 2016 & 1.41 & 4.49 & 25492.03 \\
\hline Ground herbicide & 1077 & 1.17 & 2.82 & 647 & 1.15 & 3.18 & 20384.27 \\
\hline Cutting plus herbicide & 1042 & 1.16 & 2.50 & 392 & 1.10 & 3.20 & 20046.93 \\
\hline Cutting & 819 & 1.15 & 2.90 & 733 & 1.18 & 3.02 & 22472.28 \\
\hline
\end{tabular}

${ }^{a} \mathrm{NPV}$ (2009) and BCR (2009) are discounted at 2\%. Aerial herbicide includes ASg and ASt; ground herbicide includes BBt, EZg, MBg, RHg, SGh; cutting includes BS and SIL; cutting plus herbicide includes BSg treatments. Treatment details are presented in Table 1.

(a) IRR of crop species

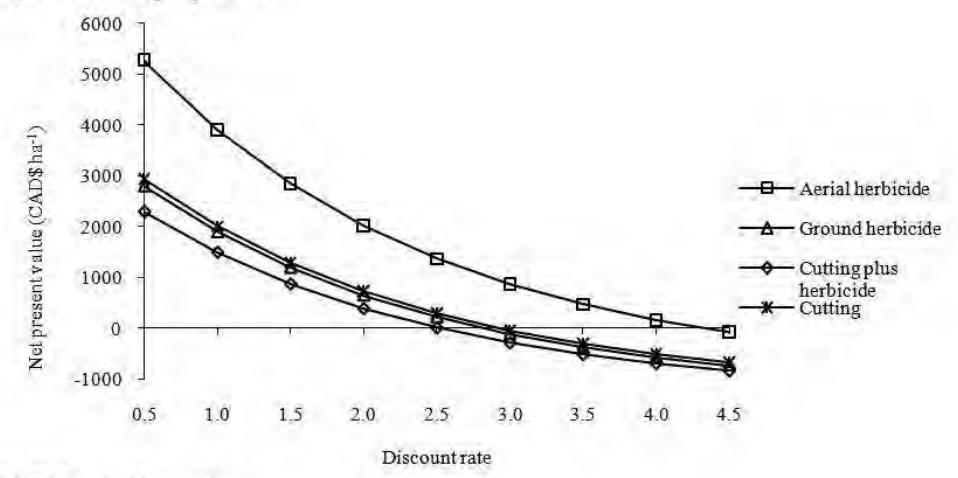

(b) IRR of all species

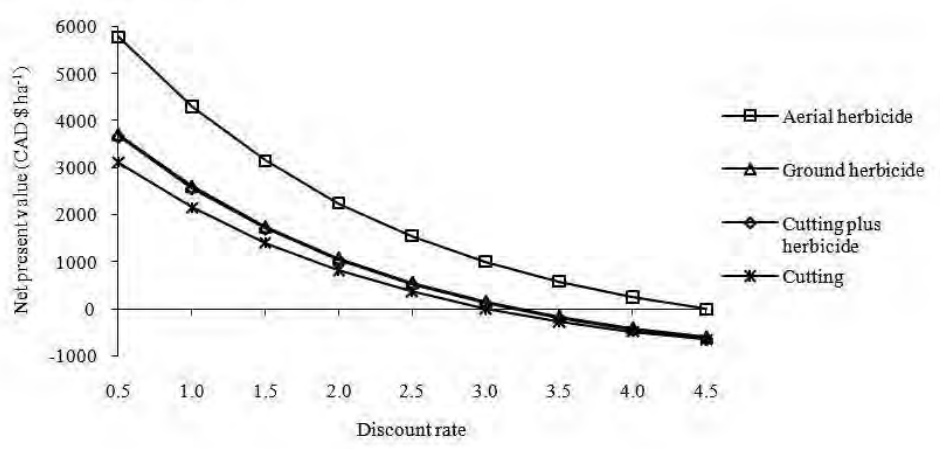

Fig. 7. Net present values of vegetation management treatment groups plotted against discount rates for internal rate of return (IRR) for (a) crop species and (b) all species sensitivity analysis. Aerial herbicide includes ASg and ASt; ground herbicide includes $\mathrm{BBt}, \mathrm{EZg}, \mathrm{MBg}, \mathrm{RHg}$, SGh; cutting plus herbicide includes BSg; and cutting includes BS and SIL treatments. Treatment details are presented in Table 1.
Results from NPV and BCR both favour the vegetation management treatment alternatives up to a $3 \%$ discount rate, which is common in long-term investments where no intermediate risks are involved. An IRR greater than 3\% indicates that investment in vegetation management alternatives is not only economically justifiable, but also leads to increased forest industry competitiveness (Baker and Powel 2005). The crop tree species on which this study is focused (black spruce, jack pine, and white spruce) cover $52 \%$ of managed Crown forest land, or $94 \%$ of managed forest land in Ontario (OMNR 2006). Since 1991 , about $30 \%$ to $40 \%$ of harvested area is treated annually (once) using forest vegetation management and $97 \%$ of those treatments are aerial application of herbicides to release desired conifer species from hardwood and herbaceous weed competition (CCFM 2010). Therefore, the most economical treatment is being used in most cases. Although, the results of our studies are applicable to the VMAP study sites only, Dacosta et al. (2011) have modelled the landscape-level effects of reduced herbicide use in two forests in northern Ontario and found that herbicide reduction would negatively affect the overall wood supply of both softwoods and hardwoods, increase costs of wood transportation and silviculture, and increase the active road network.

We recommend that additional analysis be carried out to determine the effects of adding environmental or social costs or modifying overhead costs, rotation ages, yields, input costs, and stem defect on NPV, BCR and IRR. In our analysis, we did not consider any environmental or social costs or risks associated with these treatments. We assumed $10 \%$ overhead cost in the analysis, which may have influenced NPV and BCR more so than IRR. We used an arbitrary rotation age of 70 years, assuming that managed conifer crop species will reach maximum productivity by this age; however, Willcocks et al. 
(1997) and Bell et al. (2011a) suggest that lower biological rotation ages are possible. Our assumptions for forest vegetation simulator may also have some implications for the projected values of total and merchantable volumes. Higher yields are possible through the use of more intensive site preparation, planting genetically improved stock, and increasing density and dispersion; however, such gains are associated with higher initial costs resulting in minimal influence on the economic benefits. Finally, we used the assumption of zero defects in trees and no intraspecific competition or natural disturbances (i.e., losses to mortality over the 70 years) in the optimization software, which might have resulted in overestimating the value of fibre production. More information about costs and consequences of various vegetation management treatments would also help to refine these assumptions to improve future stand-level economic analyses.

\section{Conclusions}

Economic benefit-cost analysis is an effective tool for investment decision making and policy formulation. We used stand-level benefit-cost analyses of 12 vegetation management treatments applied at six study sites in northern Ontario to evaluate net present value (NPV), benefit-cost ratio (BCR), and internal rate of return (IRR) for the resulting tree crop at 70 years following treatments. Under the assumptions used in this case study, we found that crop trees in treated plots produced higher projected gross total and merchantable volumes and value of fibre produced than did those in untreated control plots. Net present value and BCR for trees in aerial herbicide treatment groups were higher than those for the other treatments; however, all vegetation management alternatives showed positive NPV for up to a $3 \%$ discount rate. Trees in aerial herbicide treatment groups had more than double (for crop species) and more than triple (for crop and non-crop species) the NPV of other treatment groups. Trees in aerial herbicide treatment groups had the highest IRR followed by those in the ground herbicide, cutting, and cutting plus herbicide treatment groups. Values of IRR greater than 3\% indicate that investment in vegetation management alternatives is economically profitable for the forest industry and may help to improve its competitiveness in forest products markets.

\section{Acknowledgements}

Financial support from the Agricultural Research Institute of Ontario for the VMAP project, Silvicultural effectiveness and consequences of using vegetation management alternatives in boreal and temperate coniferous forests, is gratefully acknowledged. We thank the Canadian Ecology Centre Forestry Research Partnership for administering the project, Lisa Buse for editing previous versions of this manuscript, and two anonymous reviewers for helping to improve the clarity and consistency of the manuscript. Special thanks go to Dave Haveman (Haveman Brothers Forestry Services) and Jerry Smith (Jackfish River Management) for providing costing information, and to John Winters (OFRI) for technical support.

\section{References}

Armson, K.A. 2005. Regeneration standards: What has the past to show us? For. Chron. 81 (6): 781-784.
Baker, H. K. and G. E. Powell. 2005. Understanding Financial Management: A Practical Guide. Blackwell Publishing, Malden, MA. 481 p. Bell, F.W., J. Dacosta, M. Penner, A. Morneault, A. Stinson, B. Towill, N.J. Luckai and J. Winters. 2011a. Longer-term volume trade-offs in spruce and jack pine plantations following various conifer release treatments. For. Chron. 87(2): 235-250.

Bell, F.W., J. Parton, N. Stocker, D. Joyce, D. Reid, M. Wester, A. Stinson, G. Kayahara, and B. Towill. 2008. Developing a silvicultural framework and definitions for use in forest management planning and practice. For. Chron. 84(5): 678-693.

Bell, F. W., K.R. Ride, M.L. St-Amour and M. Ryans. 1997. Productivity, cost, efficacy and cost-effectiveness of motor-manual, mechanical, and herbicide release of boreal spruce plantations. For. Chron. 73: 39-46.

Bell, F.W., N. Thiffault, K. Szuba, N.J. Luckai and A. Stinson. 2011b. Synthesis of silviculture options, costs, and consequences of alternative vegetation management practices relevant to boreal and temperate conifer forests: Introduction. For. Chron. 87(2): 155-160. Boateng, J. 1996. Past and future trends in forest vegetation management in B.C. In P.G. Comeau, G.J. Harper, M.E. Blache, J.O. Boateng and L.A. Gilkeson. (comps.). Integrated Forest Vegetation Management: Options and Applications. Proc. Fifth B.C. Forest Vegetation Management Workshop, Nov. 29-30, 1993, Richmond, B.C. pp. 1-4. Can. For. Serv./ B.C. Min. For., Joint Publ., Victoria, BC. FRDA Rep. 251.

Buda, N.J. and R.G. White. 2007. Forest regeneration standards in Ontario: A historical perspective. Ont. Min. Nat. Resour., Northwest Sci. Info., NWSI Info. Rep. IR-006. 16 pp. + append.

Campbell, H. and R. Brown. 2003. Benefit Cost Analysis: Financial and Economic Appraisals Using Spreadsheets. Cambridge University Press. Cambridge, UK. 347 p.

[CCFM] Canadian Council of Forest Ministers. 2010. National Forestry Database [online]. Available at http://nfdp.ccfm.org/ data/comp_96e.html [Accessed March 2010].

Comeau, P.G., B.S. Biring and G.J. Harper. 1999. Conifer response to brushing treatments: A summary of British Columbia data. B.C. Min. For., Res. Br., Vancouver, BC. Ext. Note 41.

Comeau, P.G. and G.J. Harper. 2009. Effects of vegetation control treatments for release of Engelmann spruce from a mixed-shrub community in southern British Columbia - Year 15 results. For. Chron. 85(4): 583-592.

Dacosta, J., K. Szuba, F.W. Bell, T. Moore, K. Lennon, J. Leach, D. Bazeley and N.J. Luckai. 2011. Modelling landscape-level effects of reduced herbicide use in two forests in northern Ontario. For. Chron. 87(2): 290-309.

Dampier, J.E.E., F.W. Bell, M. St-Amour, D.G. Pitt and N.J. Luckai. 2006. Cutting versus herbicides: Tenth-year volume and release cost-effectiveness of sub-boreal conifer plantations. For. Chron. 82(4): 521-528.

D'Anjou, B. 1996. Chemical and manual treatments - Coastal B.C. In P.G. Comeau, G.J. Harper, M.E. Blache, J.O. Boateng and L.A. Gilkeson (comps.). Integrated Forest Vegetation Management: Options and Applications. Proc. Fifth B.C. Forest Vegetation Management Workshop, Nov 29-30, 1993, Richmond, B.C. pp. 59-60. Can. For. Serv./ B.C. Min. For., Joint Publ., Victoria, BC. FRDA Rep. 251.

Dubeau, D., L.G. DeBel and D. Imbeau. 2003. Integrated study of brush saw operators in Quebec. Research Note, Tabled at XII World Forestry Congress by the Ministère des Ressources naturelles, de la Faune et des Parcs du Québec. Available at http://www.mrn.gouv.qc. ca/english/publications/forest/publications/dubeau-a.pdf [Accessed Dec. 8, 2010].

[ESSA] ESSA Technologies Ltd. 2008. FVS Ontario user guide: Forest stand growth projection modelling system. Version 3.08. ESSA Technologies Ltd., Vancouver, BC.

Fortier, J. and C. Messier. 2006. Are chemical or mechanical treatments more sustainable for forest vegetation management in the context of the TRIAD? For. Chron. 82(6): 806-818. 
Heaps, T. and B. Pratt 1989. The social discount rate for silvicultural investments. Can. For. Serv., Pac. For. Cent., Victoria, BC. FRDA Rep. 071.

Hearnden, K.W., S.V. Millson and W.C. Wilson. 1992. A report on the status of forest regeneration. Ont. Indep. For. Audit, Ont. Min. Nat. Resour., Toronto, ON.

Heineman, J.L., S.W. Simard, D.L. Sachs and W.J. Mather. 2005. Chemical, grazing, and manual cutting treatments in mixed herb-shrub communities have no effect on interior spruce survival or growth in southern interior British Columbia. For. Ecol. Manage. 205: 359-374.

Johansson, P.O. and K.G. Löfgren. 1985. The Economics of Forestry and Natural Resources. Basil Blackwell, Oxford, UK. 305 p. MacDonald, P.M. and G.O. Fiddler. 1993. Feasibility of alternatives to herbicides in young conifer plantations in California. Can. J. For. Res. 23(10): 2015-2022.

Manley, B. 2010. Discount rates used for forest valuation - Results of 2009 survey. N. Z. J. For. 54(4): 19-23.

McClain, K.M., D.M. Morris, S.C. Hills and L.J. Buse. 1994. The effects on initial spacing on growth and crown development for planted northern conifers: 37-year results. For. Chron. 70(2): 174-182. McKenney, D. W., N. Beke, G. Fox and A. Groot. 1997. Does it pay to do silviculture research on slow growing species: For. Ecol. Manage. 95: 141-152.

[NRCan] Natural Resources Canada. 1995. Silvicultural terms in Canada. $2^{\text {nd }}$ ed. Natural Resources Canada, Canadian Forest Service, Ottawa, ON. 109 p.

Nautiyal, J. C., J.S. Williams, M.R. Innes, L. Gravelines and A. Ghebremichael. 2001. Financial Evaluation. In R.G. Wagner and S. Colombo (eds.). Regenerating the Canadian Forest: Principles and Practice for Ontario. pp. 589-602. Fitzhenry \& Whiteside, Markham, ON.

Nicholson, J. 2007. Survey of plantations established between 1998-2000 (6-8 years of age) on eastern Crown land without her-bicides. Nova Scotia Dept. Nat. Resour., For. Res. Rep. FOR 2007-7 No 83.

[OMNR] Ontario Ministry of Natural Resources. 2006. State of the Forest Report 2006. Appendix I. Forest Resources of Ontario 2006. Ont. Min. Nat. Resour., Toronto, ON.

[OMNDMF] Ontario Ministry of Northern Development, Mines and Forestry. 2010. Ontario's Forest Industry (last modified: August 04, 2010) [online]. Available at http://www.mndmf.gov.on.ca/ forestry/forest_industry_e.asp [Accessed Oct. 15, 2010].

Pitt, D.G and F.W. Bell. 2005. Juvenile response to conifer release alternatives on aspen-white spruce boreal mixedwood sites. Part I: Stand structure and composition. For. Chron. 81(4): 538-547.

Pitt, D.J., A.E. Morneault, P. Bunce and F.W. Bell. 2000. Five years of vegetation succession following vegetation management treatments in a jack pine ecosystem. North. J. Appl. For. 17: 100-109.
Pitt. D.G., R.G. Wagner and W.D. Towill. 2004. Ten years of vegetation succession following ground-applied release treatments in young black spruce plantations. North. J. Appl. For. 21(3): 123-133. Random Lengths Yearbook. 2009. Forest product market prices and statistics. Vol. 45. Random Lengths Publications, Inc., Eugene, OR. Simard S.W., J.L. Heineman, W.J. Mather, D.L. Sachs and A. Vyse. 2001. Effects of operational brushing on conifers and plant communities in the southern interior of British Columbia, Results from PROBE 1991-2000 Protocol for Operational Brushing Evaluations. Res. Prog., Min. For., Land Manage. Handb. No 48.

Statutes of Ontario. 1995. Crown Forest Sustainability Act, revised. R.S.O. 1998. Chapter 25 and Ontario Regulation 167/95. Toronto, ON. Swift, K.I. and F.W. Bell. 2011. What are the environmental consequences of using silviculturally effective forest vegetation management treatments? For Chron. 87(2): 201-216.

Thiffault, N. and V. Roy. 2010. Living without herbicides in Québec (Canada): historical context, current strategy, research and challenges in forest vegetation management. Eur. J. For. Res. DOI 10.1007/s10342-010-0373-4.

Thompson, D.G. and D.G. Pitt. 2003. A review of Canadian forest vegetation management research and practice. Ann. For. Sci. 60(7): 559-572.

Thorpe, S. 1996. Chemical and Manual Treatment in the Northern Interior. In P.G. Comeau, G.J. Harper, M.E. Blache, J.O. Boateng and L.A. Gilkeson. (comps.). Integrated Forest Vegetation Management: Options and Applications. Proceedings of the fifth B.C. Forest Vegetation Management Workshop, November 29 and 30, 1993, Richmond, B.C. pp. 61-66. Can. For. Serv./ B.C. Min. For., Joint Publ., Victoria, BC. FRDA Rep. 251.

Wagner, R.G, K.M. Little, B. Richardson and K. McNabb. 2006. The role of vegetation management for enhancing productivity of the world's forests. Forestry 79(1): 57-79.

Wiensczyk, A., K.I. Swift, A. Morneault, N. Thiffault, K. Szuba and F.W. Bell. 2011. An overview of the efficacy of vegetation management alternatives for conifer regeneration in boreal forests. For Chron. 87(2): 175-200.

Willcocks, A.J., F.W. Bell, J. Williams and P.N. Duinker. 1997. A Crop-planning Process for Northern Ontario Forests. Ont. Min. Nat. Res., Northwest. Ont. For. Tech. Develop. Unit, Thunder Bay, ON. 159 p.

Wyatt, S., M.-H. Rousseau, S. Nadeau, N. Thiffault and L. Guay. 2001. Social concerns, risk and the acceptability of forest vegetation management alternatives: Insights for managers. For Chron. 87(2): 274-289.

Zakrzewski, W.T., F. Schnekenburger and P. Kozlowski. 2010. Tools for optimizing timber product mix: User's guide for VisualizerBuck. Ont. Min. Nat. Resour., Ont. For. Res. Inst., Sault Ste. Marie, ON. For. Res. Inf. Pap. No. 174. 18 p. + append. 